\title{
THE STRATEGIC MANAGEMENT OF LAKE TOBA DEVELOPMENT
}

\author{
Posma Sariguna Johnson Kennedy \\ Christian University of Indonesia \\ posmahutasoit@gmail.com
}

\begin{abstract}
To fulfill Sustainable Development Goals which is a document that become a reference in the framework of development in the world, one of the goals is the suistainable tourism issue for welfare. The government wants to make Lake Toba as one of the priority tourist destinations. Lake Toba with the beauty of the largest volcanic caldera in the world can invite demand for both domestic and foreign tourists. It is important to improve the environmental condition of the lake itself and how the infrastructure to reach the tourist destinations. The main purpose of this paper is to analyze the strategic management of Lake Toba development. The research method used is qualitative method. The government wants the best strategy with various implementations to prepare Lake Toba as a world tourism destination.
\end{abstract}

Key Words: Lake Toba, Strategic Management, Tourism Destination.

\section{INTRODUCTION}

Lake Toba has very high potential tourism. The main attraction is the lake itself. Lake Toba is expected to be a world-class environmentally-friendly destination that focuses on its volcanic heritage combined with Batak culture. In the middle of Lake Toba there is an island called Samosir Island. Many things are popular in Samosir Island. Among them are Chairman of Batu Raja Siallagan, Tomb of King Sidabutar, Ambarita, Parbaba Beach, Gunung Pusuk Buhit, there is also Tuktuk Village as the main accommodation area.[BPIW, 2015]

Lake Toba is a land that inhabited by individuals and ethnic groups of Batak Toba, living at an altitude of 900 $\mathrm{m}$ above sea level. This lake is formed from eruption of volcanic mount. The eruption had an impact sprayed the crater which was filled with a very large water debit. The people of Sumatera Utara consist of various ethnic groups such as Melayu, Batak Karo, Batak Toba, Mandailing Batak, Batak Angkola, Batak Simalungun, Batak Pakpak, Nias and another ethnic groups Minangkabau, Aceh, Jawa, etc). Population in Lake Toba area is dominated by Batak Toba, Batak Karo, and Batak Simalungun. Lake Toba is one of the pride Batak Toba community that is very useful for the source of life. [BPIW, 2015]

The main objective of this paper is analyze the strategic to national tourism of Lake Toba to increase tourist visits, both domestic and foreign. This is because there is a desire of government to create new tourist destinations such as Bali which has long been known by international tourists, one of which is 
Lake Toba to increase national income other than taxes.

\section{LITERATURE REVIEW}

\subsection{Supply and Demand in Tourism}

The function and the tourism system, consists demand or the market as tourists who visit, and supply as a tourist destination itself. The demand and supply of a tourism activity is a major force in tourism planning. The demand and supply, as a market, determines what tourists want, the needs and ability of tourists to pay. Market can be categorized, but will change over time. Supply and demand must be developed, not only as a response from the market but also as one of the geography and management factors associated with the tourist destination. Planning in the tourism development should be able to run with both strengths in the same time.

There are two things that can be offered to tourists, namely products and services. The tourism product is the overall coverage of a product that is destined for a person or consumed by a person during a tourist activity. Service is a service that tourists receive during a tour. There are three basic components forming tourism products and tourist destinations, namely tourist attraction, amenitas and accessibility. Attraction is an advantage that can be used to "sell" the area to attract tourists to conduct tourism activities. Amenitas is a comfort supported by various completeness of facilities and infrastructure supporting tourism activities. The availability of facilities and infrastructure of tourism activities can affect the sustainability of tourism activities in an area.[Haynes, 2000]

\subsection{Strategy Management as a Foun- dation for Planning}

The process of strategy
management is the way in which

strategic planners set goals and make decisions. Some important steps are formulated: 1) Setting the vision, mission and objectives of the company; 2) Examining threats, opportunities strengths, and weaknesses (SWOT analysis); 3) Consider alternative strategies; 4) Choosing a Strategy; 5) Implementation of Strategy; 6) Evaluation Strategy.

Vision is a desire for a condition in the future that will be in accordance with the ideals of all company members. The mission is a fundamental purpose that distinguishes a company from other similar companies and that explains its operational coverage. Purpose is the translation of the mission. To formulate a strategy, the most important step is to conduct an environmental analysis. This analysis covers the environment outside the company (external environment) and the environment within the company itself (internal environment). Both results will be combined to get a picture of the conditions that are being faced by the company, and also will be faced in the future. From the external and internal environment circumstances we know the SWOT of the company. SWOT analysis is a systematic way to identify internal company factors based on the assumption that an effective strategy will maximize the strengths and opportunities and minimize the weaknesses and threat, [Pearce and Robinson, 2014]

From the SWOT analysis it can be determined the alternative strategies. In the implementation of the strategy. Strategies should be implemented in accordance with the stated goals and plans. The implementation of the strategy spells out more clearly how the strategy choices are realized as planned. [David, 2017]

The last stage is the evaluation to see how far the results of the stages are going through, as well as the feedback in implementing the strategy management process. [Jauch and Glueck, 1988] 


\section{RESEARCH METHOD}

The Paper Research Method was developed using descriptive qualitative research literature research methods. Secondary data are obtained from Central Bureau of Statistics of Samosir District [BPS Kabupaten Toba Samosir. 2017], Regional Infrastructure Development Board [BPIW, 2015], and especially from Horwath HTL Tourism Hotel Leisure Report under the title "Market Analysis and Demand Assessment of Lake Toba" [Howarth, 2015]. This paper is in support of World Bank Selection \#1223583 as Howarth's report in developing Lake Toba tourism destinations. Several field observations are also conducted. Strategic management of the development of this Lake Toba destination uses the structure of thinking as shown below:

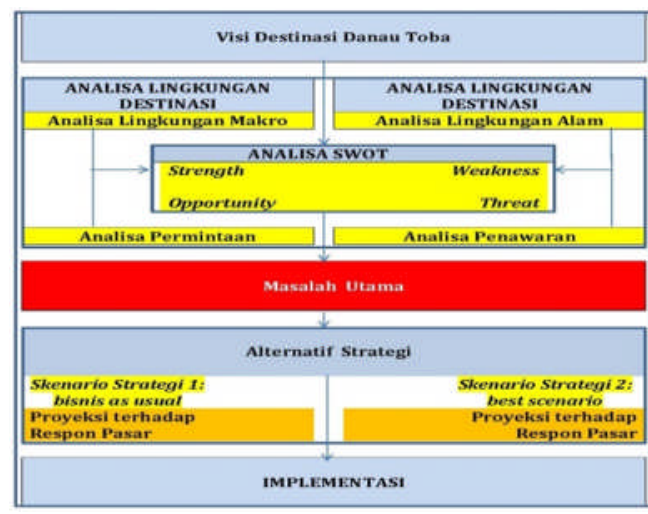

Figure 1: Strategic Management

Source: from various sources

\section{RESULT AND DISCUSSION}

Here is the analyze of strategy management for planning the development of Lake Toba tourism destination in determining the decision making.

\subsection{Vision of Lake Toba}

Government of North Sumatra Province wants to realize the vision: "Realizing Lake Toba Area as the Water Source of People's Life, Kampung Center for Indigenous Batak Community and Sustainable Tourism Area of the World". The mission are: Realization of the environment of Lake Toba Area; Realization of infrastructure improvements in support of regional development; Realization of Lake Toba as a world-class tourism area connected with domestic and global tourism market; Realization of region-based commodity-based economy of superior value added and able to compete in the global market; and Realization of local communities as the main actors in the economic activities of the region. [BPIW, 2015]

The expected goal is the significant growth of visitors both by domestic and foreign tourists.

Table 1. The Number of Visitors Growth

\begin{tabular}{|c|c|c|c|c|}
\hline & 2015 & 2021 & 2026 & 2041 \\
\hline $\begin{array}{l}\text { Foreig } \\
\text { ners }\end{array}$ & 58.709 & 81.070 & $\begin{array}{l}116.85 \\
0\end{array}$ & $\begin{array}{l}264.65 \\
0\end{array}$ \\
\hline $\begin{array}{l}\text { Domes } \\
\text { tic }\end{array}$ & $\begin{array}{l}1.743 . \\
500\end{array}$ & $\begin{array}{l}2.041 . \\
950\end{array}$ & $\begin{array}{l}2.498 \\
160\end{array}$ & $\begin{array}{l}3.083 . \\
420\end{array}$ \\
\hline $\begin{array}{l}\text { TOTA } \\
\text { L }\end{array}$ & $\begin{array}{l}1,802, \\
209\end{array}$ & $\begin{array}{l}2,123, \\
020\end{array}$ & $\begin{array}{l}2,615, \\
010\end{array}$ & $\begin{array}{l}3,348, \\
070\end{array}$ \\
\hline
\end{tabular}

Note: The number of visitors including day visitors and includes passengers on board.

\begin{tabular}{|l|l|l|l|}
\hline & $\begin{array}{l}2016- \\
2021\end{array}$ & $2022-2026$ & $\begin{array}{l}2027- \\
2041\end{array}$ \\
\hline Foreigners & $5.5 \%$ & $7,6 \%$ & $5,6 \%$ \\
\hline Domestic & $2,7 \%$ & $4,1 \%$ & $1,4 \%$ \\
\hline TOTAL & $2,8 \%$ & $4,3 \%$ & $1,7 \%$ \\
\hline
\end{tabular}

Source: Horwath ( 2015) 


\subsection{Environmental Analysis of Tourism Destination 4.2.1 Macro Environmental Analysis}

The Indonesian Government desire to increase significant revenue from the tourism sector as non-oil revenues. Thus established a program of tourism development with 10 priority objectives. Through the National Medium-Term Development Plan (RPJMN). A number of objectives have been set up to enhance the role of tourism in the Indonesian economy.

In 2015-2019, the Government and the Ministry of Tourism target the increase of international visitors from 9 million to 20 million, domestic visits from 250 million to 275 million, tourism contribution to GDP from 4 percent to 8 percent, tourist income from Rp120 trillion to Rp240 trillion, Indonesia ranked in Tourism and Tourism Rank from 70th place to 30th, and tourism sector workforce from 11 million to 13 million workers.

\subsubsection{Natural Environmental Analysis}

There is a deterioration in water quality as a result of the various wastes dumped into the lake causing pollution. Existing wastes are domestic waste, agricultural waste, waste from aquaculture in floating net, as well as waste oil derived from water transport activities. More than $50 \%$ of solid waste in 7 districts around Lake Toba is not collected and disposed of properly. There is a destruction of forest areas, in the form of deforestation for various purposes around the lake. Causes fluctuations in water flow into the lake resulting in erosion and increased sedimentation. Drainage does not have a direct impact on visitors around Lake Toba.

Less than $10 \%$ of the population in 3 major tourism districts do not have access to PLN power supplies. Power demand for tourism activities is smaller than $5 \%$ of total demand.
Approximately, $90 \%$ of the population in 3 major tourism districts do not have access to PDAM water supply. Water demand for tourism activities is smaller than $5 \%$ of total demand. About $20 \%$ of households in 3 major tourism districts are not equipped with adequate sanitation facilities.

\subsubsection{Demand Analysis}

The number of domestic visitors represents $92 \%$ of total visitors to Lake Toba. Day visitors with an estimated number of 483,000 visits by 2015 . Visitors who live in non-commercial accommodation (friends and relatives) with an estimated number of 598,000 visits by 2015. Visitors staying in commercial accommodation with an estimated arrival amount of 662,500 by 2015. 95\% of Indonesian domestic tourists come for holiday destinations. Their arrival increased in the last 5 years. The number of visitors to international tourists is still very limited, ie as many as 58,700 tourists in 2015. International visitors represent only $3 \%$ of the total visitors. They mostly live in commercial accommodation (120,700 night guests with an average duration of 2.1 nights).

International visitors have continued to increase over the last 5 years. Most foreign visitors come from Malaysia and Singapore (50\% and $10 \%$ respectively).

\subsubsection{Supply Analysis}

The length of national road in Danau Toba is $542.98 \mathrm{~km}$. Consists of, the length of provincial road is 172,74 $\mathrm{km}$, the length of district road is $4,170,59$ $\mathrm{km}$ and the length of ring road in Danau Toba area is $277,08 \mathrm{Km}$. The existing road network in the Lake Toba area is mostly quite good, especially the road that connects to the district capital.

Airport Silangit, has terminal capacity - 36,500 passengers/year, adequate capacity (17,800 passengers handled by 2015). Runway Capacity $2400 \mathrm{~m}$, no parallel taxiway, capable of 
handling 16 aircraft per hour, adequate capacity (currently 2 hours peak movement). Sibisa Airport, has runway: $750 \mathrm{~m}$ x $18 \mathrm{~m}$, terminal: $120 \mathrm{~m}^{2}$.

For trains, there are no rail connections to the core tourist areas of Lake Toba. Medan-Pematang Siantar path with a train journey is approximately 4 hours. It is estimated that $5 \%$ of foreign visitors and $10 \%$ of domestic visitors use trains/public transport.

Lake transportation, several small ports (no proper docking facilities), small boat, service every half hour. It mainly operates in Tigaraja -Tomok and Tigaraja - Tuk Tuk, adequate capacity with 28 fleet, 30 capacity per ship. There are 2 ferry operators RORO: Ajibata Tomok privately operated and Balige Onan Runggu \& Simanindo - Tigaras operate in public. Ferry RORO every 2.5 hours. Current capacity and frequency are still sufficient.

Local collector roads along the coast of Samosir island are poorly linked between subdistricts, but on some roads connecting sub-districts are quite good. Medan to Tebing Tinggi $(83 \mathrm{~km})$ with travel time 2 hours 20 minutes. Tebing Tinggi to Pematang Siantar $(52 \mathrm{~km})$, travel time 1 hour 40 minutes. Pematang Siantar to Parapat (43 km), travel time 1 hour 10 minutes. Parapat to Balige $(60 \mathrm{~km})$, travel time 1 hour 30 minutes. Balige to Siborong Borong (19.6km), travel time 1 hour. Toba - Berastagi Medan via Tigaras $(147 \mathrm{~km})$, travel time 6 hours.

By the end of 2015, there are a total of 131 hotels (3,391 rooms) in 3 main districts that surround Lake Toba. Only 16 hotels (more than 10\%) have a 4 star rating. Star hotels focus on major tourist towns, Tuktuk (Samosir District) and Parapat (Simalungun Regency). Simalungun and Samosir regencies dominate star hotels with a total of 116 hotels. The maintenance of hotels is generally below standard. The average room is composed of 22.9 small rooms. The growth of hotel rooms from 2009 to 2015 in 3 main districts are: Simalungun by $1 \%$, Samosir $3 \%$ and Toba Samosir by $6 \%$. Overall, 3 Toba districts are targeting growth of around 3\% in 6 years from 2015.

\subsection{SWOT Analysis}

We can deliver some strength, weakness, opportunity and threat factors of destination.

\subsubsection{Strength}

Lake Toba is the rich natural beauty lake as a world-class attraction. A strong awareness that Lake Toba is a tourist destination at national and international level. Good flight connections between Indonesia (Medan) and Southeast Asian countries. Culture and way of life Batak strong and unique in Indonesia. Lake Toba is the largest volcanic caldera in the world, created by the eruption 74,000 years ago which is the largest eruption of the last 2 million years.

\subsubsection{Weakness}

Road infrastructure between Medan and Parapat is poor. The environment is deteriorating. Low quality and less varied hotel accommodation. Company demand and MICE are very limited in increasing occupancy. Limited number and variety of supporting tourism facilities, such as restaurants, recreational activities retail and commercial. Limited investor interest. Fog events, almost every year in the middle of the year caused by forest fires have a negative impact on the visit.

\subsubsection{Opportunity}

Road improvement between Medan- Tebing Tinggi is expected to reduce travel time. There is strong support from the central government for development and promotion. Possibility to introduce recreational attractions (boat trips, water sports and activities, golf, hiking and bcycling). Lake Toba tourism 
is possible packed with other attractions (shopping in Medan, Brastagi and Bukit Lawang). The government has applied for Geopark Toba Caldera written on the UNESCO Global Geopark Network. Opportunity to promote Batak culture to tourists with the new Kualanamu airport. More air connections can be built with other regional gateway towns.

\subsubsection{Threats}

Absence of proper waste management, waste disposal, deforestation and commercial fishing methods, and smoke pollution. Negative natural lakeside regulations are not eliminated by the district/provincial government, that allow for illegal construction that damages the lakeside. Lake Toba has an earthquake risk (occurred around Bukit Pusuk Bukit, especially in 1987 along the south bank).

From SWOT analysis above, the main problem in Toba Lake tourism destination is: environmental degradation is currently a significant threat to the success of development in future; and Lake Toba is a natural asset with poor road accessibility.

\subsection{Alternative Strategy}

From the environmental analysis of Lake Toba Destination Tourism and SWOT analysis, as well as the main problems faced, two strategic scenarios are defined. Namely, the first strategy scenario as business as usual and second strategy scenario as the best scenario.

\subsubsection{Scenario Strategy 1: Business as Usual Strategy}

This strategy is described that the degradation of Lake Toba natural environment continues to occur, and travel time through the road will still harm the visitors and potential investors. Projections for the market response are [Howarth, 2015]:

1. Demand will remain unchanged significantly.
2. If environmental degradation continues, it will dampen visitor interest in tourism destinations

3. Growth in accommodation and tourism activities will be in minimal demand .

4. The average duration of stay will remain the same as the past.

5. The visitor's spending will remain low.

6. Projected growth in domestic visitors will slow down

7. Forecast of domestic visitors to Lake Toba will continue to grow but in limited rate

8. The attractiveness of Lake Toba is low due to the degradation of environmental and road access

9. Due to environmental degradation, Lake Toba will lose its appeal.

\subsubsection{Scenario Strategy 2: Best Scenario Strategy}

This strategy is described as an integrated tourism master plan where there are real efforts to rehabilitate, preserve the lake environment, facilitate public investment in bike lanes and hiking, as well as the development of other new tourism facilities. Accessibility from Medan and North Coast of North Sumatra increases between 2016 and 2021 (where the travel time from Medan to Parapat decreases from more than 5 hours to a maximum of 2 hours 30 minutes. Faster flight scheduling between Airports in Jakarta and Silangit to facilitate weekend travel From Jakarta Mining MICE facilities and leisure activities, marinas, hotels and real estate in major accommodation areas in Parapat and Samosir Island. The projection of the market response to this best scenario is [Howarth, 2015] :

1. The market potential is very high as there will be an increase in day trips and stay briefly at Lake Toba from Medan and surrounding areas

2. Increased visitor accessibility will lead to increased investment in 
commercial offerings in Toba Lake tourism destinations.

3. In 2016-2021, although accessibility has not been fully improved it can encourage realization of some investments.

4. In 2021-2041, the attractiveness of objectives increases.

5. The average duration of stay and tourist expenditure will increase over time.

6. The projected growth of domestic tourist arrivals experienced high and significant growth.

7. By 2041 it is estimated that day visitors from the Medan area will increase from 483,000 (2015) to 902,000 (2041)

8. Travel on non-commercial accommodation grows faster

9. Lake Toba will increasingly attract visitors from the provinces outside of North Sumatra.

10.Produce 4.5 times more international visitors by 2041 compared to 2015 .

\subsection{Implementation by the Govern- ment}

To realize the development of tourism destinations of Lake Toba significantly, the government has established an Authority Management Agency of Lake Toba Tourism Area based on Presidential Regulation No. 49 of 2016. Some plans will be and are being done.

First, begins with the cleaning of the environment of Lake Toba as a whole. The government will ban the existence of floating net cages. Fish production from keramba in Lake Toba reaches 80 thousand tons of fish in 2015. A total of 51 thousand tons of fish come from community owned cages, while the rest are from corporate keramba. But, the carrying capacity of Lake Toba is only 50 thousand tons every year. Damage to the lake marked the existence of 5600 floating net cages that produce high organic waste. In addition, the damage from industrial timber estate permits (HTI) and truckloads from Toba Pulp Lestari. Restoration of Lake Toba without waste from keramba is now the homework of seven districts that overshadowed the lake, namely Samosir, Toba Samosir, Humbang Hasundutan, North Tapanuli, Simalungun, Dairi and Karo.

Second, is by optimizing the production from the local area. For example for fruits, coffee, vegetables and a variety of food Toba lake mainstay. There are seven districts around Lake Toba and all agree on the development. They want all area of around Lake Toba enjoy the rise of destination.

Third, is from the connectivity side. Infrastructure becomes important in the development. There are the ring road on Samosir Island and a major road that passes towards Kualanamu Airport. Developing the $97 \mathrm{~km}$-long SiantarParapat toll road, which will start in 2017, is expected to be completed by 2019. Extend the airport runways of Silangit in North Tapanuli and Sibisa Airport. Prepared a ferry to connect from the ground to Samosir. The waters between Tano Ponggol and Samosir Island will be deepened, in order to facilitate the boat to enter the lake Toba. It will be provided 600 ha of greenery land. Inside the tourist area will be built 5 five-star luxury hotel, convention center, and golf course. 600 hectares land is also included for the Land Authority of Tourism Agency. There are new attractions, namely Taman Bunga Nusantara.

Fourth, is the strengthening of the side history of Lake Toba. The history can be an attraction to come to the lake. Lake Toba is a large natural volcano, is the largest caldera lake in the world located in the province of North Sumatra, $176 \mathrm{~km}$ to the west of Medan as the capital of the province. [BPIW, 2015] 


\section{CONCLUSION}

The development of Lake Toba's destinations needs to be done jointly by the government with the community. If the future strategy is done by business as usual scenario, it will remain to the detriment of visitors and potential investors. The degradation of Lake Toba natural environment continues to occur.

\section{REFERENCES}

BPIW, Agency for Infrastructure Development Wilayah. (2015). Inkubasi Kawasan Danau Toba. Pusat Perencanaan Infrastruktur Kementrian Pekerjaan Umum dan Perumahan Rakyat.

BPS Kabupaten Toba Samosir. (2017). Kabupaten Toba Samosir dalam Angka. BPS Kabupaten Samosir.

David, Fred R and David, Forest. 2017. Strategic Management: Concepts and Cases. Publisher: Pearson

Haynes, P., Fryer, G. (2000). "Human resources, service quality and performance: a case study", International Journal of ment.
For that reason, the best scenario should be done. Economic impacts with the best scenario allow the projected number of visitors to Lake Toba to increase almost twice from 1.8 million in 2015 to 3.3 million in 2041. Investments will also rise to anticipate future demand increases.

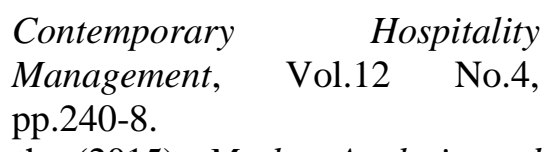
Horwath. (2015). Market Analysis and Demand Assessment Lake Toba. Crowe Howarth Hotel, Tourism, Leisure Services

Jauch, Lawrence R. and Glueck, William F. (1988). Business Policy and Strategic Management. New York: McGraw-Hill

Pearce, John A.; Robinson, Richard B. (2014). Strategic Management. McGraw-Hill Education/Irwin Manage 